\title{
JUSTICE SCALIA'S USE OF SOURCES IN STATUTORY AND CONSTITUTIONAL INTERPRETATION: HOW CONGRESS ALWAYS LOSES
}

\section{INTRODUCtion: SOURCES ARE IMPORTANT to JUSTICE SCALIA}

For Justice Scalia, sources of arguments matter. According to Justice Scalia, the Constitution limits the sources courts may cite in written opinions. One source Justice Scalia views as iniproper is the legislative history compiled by Congress. Though his antipatly toward legislative history was known before lie joined the Supreme Court, ${ }^{1}$ over time he has reasserted this view with renewed vigor.

However, Justice Scalia uses a different rule for sources of authority in his constitutional opinions. Althougl he adheres to a "textualist" approach when interpreting statutes, he adopts an "originalist" stance with regard to the Constitution. These theories of interpretation profoundly differ: The textualist looks only at the words of a statute, whereas the originalist examines both the words and additional sources that shed light on what the words originally were intended to mean.

This Note examines Justice Scalia's choices and uses of sources in his statutory and constitutional opinions. The reasons he gives for his mconsistent treatment of sources fail to persuade, and a case could be made that precisely the opposite approach would be more appropriate. Yet perhaps the most significant aspect of Justice Scalia's approach to the use of sources (in either statutory or constitutional adjudication) is the effect it has on redistributing power among the three branches of government. Refusing to consult legislative history reduces the power of the legislative branch, and it allows both the executive (especially including administrative agencies) and the judiciary more room to promulgate and pursue their own views. In contrast, willinguess to consult the Constitution's "legislative history" agam reduces the power of the legislative branch: The judicial rather than the legislative interpretation of a constitutional provision is more likely to determine whether the statute in question is unconstitutional. As long as the legislative branch is controlled by

1. See Comment, The Appellate Jurisprudence of Justice Antonin Scalia, 54 U. CHI. L. REV. $705,722-26$ (1987). 
a different political party than controls the other branches, Justice Scalia's interpretive practices have clear practical consequences.

\section{Eschewing Legislative History IN STATUTORY INTERPRETATION}

\section{A. The Rule}

Justice Scahia lias not hidden his disdain for the use of legislative history. He would be liappy if Congress produced no legislative history at all, ${ }^{2}$ and le thinks it has no place in determining the "ordinary meaning" 3 or the constitutionality ${ }^{4}$ of a statute.

In a large number of opinions, Justice Scalia avoids using legislative history in a statutory interpretation simply by asserting tliat the Court could have reached the same result based on the language of the statute. ${ }^{5}$ Justice Scalia's position in these concurrences can be understood best as an arguinent for judicial economy. Every canon of statutory construction supports the conclusion that the court should start from the text of the statute. ${ }^{6}$ If the statutory text supplies an answer to the issue, the judge need not delve further into the legislative record. When statutory language is clear, tlie judge would only use the legislative history to confirm whit slie already discovered. And even if the judge finds a clear conflict between the legislative history and statutory language, common precepts of statutory construction would require her to ignore the legislative listory in interpreting the statute. ${ }^{7}$

Anotlier reason Justice Scalia suggests for ignoring legislative history is the process by which soine committee reports are generated. In

2. Sable Communications v. FCC, 109 S. Ct. 2829, 2840 (1989) (concurring) ("Neither due process nor the First Amendment requires legislation to be supported by committee reports, floor debates, or even consideration, but only by a vote.").

This Note varies Bluebook style by presuming that all decisions, whether majority, concurrence, or dissent, are authored by Justice Scalia, unless otherwise indicated.

3. Green v. Bock Laundry Machine Co., 109 S. Ct. 1981, 1994 (1989) (concurring in the judgment).

4. Sable Communications, 109 S. Ct. at 2840; see also Edwards v. Aguillard, 482 U.S. 578, $610-40$ (1987) (dissenting). But see Morrison v. Olson, 487 U.S. 654, 701 (1988) (dissenting) (drawing on a Conference report to demonstrate unconstitutionality of Ethics in Government Act).

5. See, e.g., Jett v. Dallas Indep. School Dist., 109 S. Ct. 2702, 2724 (1989) (concurring) ("I join Parts I and IV of the Court's opinion, and Part III except insofar as it relies upon legislative history."); H.J., Inc. v. Northwestern Bell Tel., 109 S. Ct. 2893, 2907 (1989) (concurring) (deriding the majority opinion for "[e]levating to the level of statutory text a phrase taken from the legislative history.").

6. For a traditional account of the canons of statutory interpretation, see R. Dickerson, The INTERPRETATION AND APPLICATION OF STATUTES (1975).

7. CTS Corp. v. Dynamics Corp. of America, 481 U.S. 69, 96 (concurring) ("I also agree with the Court that the Indiana Control Shares Act is not pre-empted by the Williams Act, but I reach that conclusion without entering into the debate over the purposes of the two statutes."). Justice 
Hirschey v. Federal Energy Regulatory Commission, a widely publicized concurrence he wrote as a judge on the District of Columbia Circuit, Justice Scalia criticized the majority's rehance on a committee report published when the Equal Access to Justice Act was extended without changes. ${ }^{8}$ In this report, the committee had asserted it was in agreement with the D.C. Circuit, and believed the Ninth Circuit had misinterpreted the law. Scalia wrote:

It is most interesting that the House Committee rejected the interpretation of the Ninth Circuit, and perhaps that datuin should be accorded the weight of an equivalently unreasoned law review article. But the authoritative, as opposed to the persuasive, weight of the Report depends entirely upon how reasonable it is to assume that that rejection was reflected in the law which Congress adopted. I frankly doubt that it is ever reasonable to assuine that the details, as opposed to the broad outlines of purpose, set forth in a committee report come to the attention of, inuch less are approved by, the house which enacts the committee's bill. And I think it time for courts to become concerned about the fact that routine deference to the detail of cominittee reports, and the predictable expansion in that detail which routine deference has produced, are converting a systein of judicial construction into a system of committee-staff prescription. ${ }^{9}$

Justice Scaha also illustrated the problem of relying on legislative history through a comical excerpt from the Congressional Record in which Senator Dole conceded that neither he nor any other Senator actually had written the committee report, and no Senator had read it in its entirety. ${ }^{10}$

Scalia elaborated on this point in United States v. Taylor, 487 U.S. 326, 345 (1988) (concurring in part):

The text is so unambiguous on these points that it must be assunied that what the Members of the House and the Senators thought they were voting for, and what the President thought he was approving when he signed the bill, was what the text plainly said, rather than what a few Representatives, or even a Committee, said it said.

Interestimgly, he usually nuakes this point in a concurrence, not a dissent, since he usually reaches the same conclusion as the other Justices.

8. Hirschey v. Federal Energy Regulatory Comm'n, 777 F.2d 1, 7-8 (D.C. Cir. 1985) (concurring).

9. Id. This passage attracted some attention at Judge Scalia's subsequent nomination hearing. See Nomination of Judge Antonin Scalia to be Associate Justice of the Supreme Court of the United States: Hearing Before the Comm. on the Judiciary, 99TH CONG., 2D SESS. 65-67 (1986) [hereinafter Confirmation Hearingsl (statemient of Senator Grassley).

This stands in stark contrast to Justice Scalia's broad reliance on rules or adjudications produced by an admimistrative agency rather than a legislative committee (regardless of whether the cabinet secretary ever had any inkling of what the subordinates were producing): "[W]e will defer, of course, to FERC's construction if it does not violate plain meaning and is a reasonable interpretation of silence or ambiguity." Mississippi Power \& Light Co. v. Mississippi ex rel. Moore, 487 U.S. 354, 380 (1988) (concurring).

10. Hirschey, 777 F.2d at 7. Justice Scalia's interpretation of this piece of legislative history, as well as his general antipathy to using legislative history in any context, is criticized in Farber \& Frickey, Legislative Intent and Public Choice, 74 VA. L. REv. 423, 437-52 (1988). Professors Farber 
The theme that staffers rather than Members of Congress create legislative history also appears in Blanchard v. Bergeron, which also involved interpretation of the Equal Access to Justice Act. ${ }^{11}$ Here, his concern was that Justice White's inajority opinion began from the premise that a group of cases nained in the committee report accompanying the Equal Access to Justice Act, which the committee highlighted as examples of proper interpretations. Again, Justice Scalia asserted that Members of Congress were ignorant of the contents of the report. ${ }^{12}$ After proclaiming congressional ignorance, lie highliglited what for him was the galling psychology of the members of committee staffs: "What a heady feeling it must be for a young staffer, to know that his or lier citation of obscure district court cases can transform them into the law of the land ...."13 Justice Scalia refused to jom the majority opinion because its process of analysis was "neither coinpatible with our judicial responsibility or assuring reasoned, consistent and effective application of the statutes of tlie Umited States, nor conducive to a genuine effectuation of congressional intent, to give legislative force to each smippet of analysis ...."14

Justice Scaha brought togetlier several reasons for rejecting legislative history in Green v. Bock Laundry Machine Co. ${ }^{15}$ That case involved a county prisoner on work-release wlio was seriously injured by an allegedly defective car washing machine at his place of employment. After the prisoner testified at trial, the defendant's attorney sought to impeacli him by questioning him about his criminal record. The plaimtiff argued that the case turned on the meaning of Federal Rule of Evidence 609(a),

and Frickey provide a larger context for the snippet of legislative history, and conclude that in fact Senator Dole did claim to have reviewed the Committee Report, and did vouch for its accuracy. See generally Costello, Average Voting Members and other "Benign Fictions": The Relative Reliability of Committee Reports, Floor Debates, and Other Sources of Legislative History, 1990 DukE L.J. 39, 67.

Another criticism of this passage is that it came from a piece of legislation unrelated to the legislation at issue in Hirschey. Finding one piece of legislative history not produced according to proper procedures does not prove that other legislative history does not merit reliance. By analogy, Justice Scalia could argue that because some Supreme Court decisions were written by clerks rather than judges, all Supreme Court opinions should be ignored.

11. 109 S. Ct. 939, 946 (1989) (concurring in part and concurring in the judgment).

12. I am confident that only a small proportion of the Members of Congress read either one of the Committee Reports in question, even if (as is not always the case) the Reports happened to have been been published before the vote; that very few of those wlio did read them set off for the nearest law library to check out what was actually said in the four cases at issue ... and that no Member of Congress came to the judgment that District Court cases would trump Johnson on the point at issue issue here....

Id. at 947.

13. Id. This is one of the few sentences in any recent Supreme Court opinon that probably was not written by a law clerk.

14. Id. For a critique of this argument, see infra text accompanying note 68 .

15. 109 S. Ct. 1981, 1994 (1989) (concurring). 
which allows the introduction of evidence of prior convictions for impeachment only when "the court determines that the probative value of admitting this evidence outweighs its prejudicial effect to the defendant ...." "16 The trial judge had not weighed the prejudicial effect in this case, behieving that Rule 609(a)(1) applies only to criminal proceedingsthe reference to "defendant" meant "criminal defendant." Justice Stevens examined a lengthy history of Bar Association committee reports, running back several decades, to find the district court's understanding of the Rule was correct. ${ }^{17}$

Justice Scalia found this method of determining the issue to be wrong because it presumed an implausible degree of knowledge on the part of Members of Congress:

I find no reason to believe that any more than a handful of the Members of Congress who enacted Rule 609 were aware of its interesting evolution from the 1942 Model Code; or that any more than a handful of them (if any) voted ... on the basis of the referenced statements in the Subcommittee, Committee, or Conference Committee Reports, or floor debates . . . ${ }^{18}$

Justice Scalia then noted that the controversy could be linited to whether the word "defendant" meant "criminal defendant," "civil plaintiff, civil defendant and criminal defendant," or "civil plaintiff, civil defendant, prosecutor and criminal defendant." 19 Because the first solution was most consistent with the meaning of the text, Justice Scalia considered the district court's interpretation correct. No need to go further, according to Justice Scaha, and Justice Stevens' historical analysis was not only superfluous but also insidious, since it "produc[es] a legal culture in which, when counsel arguing before us assert that 'Congress has said' something, they now frequently mean, by 'Congress,' a comnittee report . . .."20 Justice Scalia saw no need to explain why such a legal culture would be undesirable.

16. FED. R. Evid. 609(a).

17. Green, 109 S. Ct. at 1986 (1942 ALI proposal) (Stevens, J., majority); id. (1953 National Conf. of Comm'rs report); id. at 1987 nn.16 \& 17 (1969 Preliminary Draft of Proposed Rules of Evidence); id. at 1988 (1971 Advisory Committee Draft). Justice Stevens also considered several conventional committee reports.

18. Id. at 1994 (concurring in the judgment). "Defendant" could not mean "civil or criminal defendant" because this would create an uneven distribution of advantage in civil cases, an "absurd result."

19. Id. Justice Blackmun, in dissent, argued that the plain language should be interpreted in conjunction with Rule 102, "to secure faimess in administration," and that allowing the benefit of weighing evidence to all litigants best aclieves this result. Id. at 1997 (Blackmun, J., dissenting) (quoting FED. R. Evid. 102). He agreed with Justice Scalia that "almost all [of the majority opinion's] history is entitled to very little weight." Id. at 1996.

20. Id. at 1995. 
Finally, Justice Scalia contends that legislative history should be ignored because it may not be directly related to the vote of legislators. In Edwards v. Aguillard the majority, relying in part on soine legislators' stated intentions, found that a Louisiana statute requiring high schools to teach "creation science" as well as "evolution science" in biology courses violated the first amendment's establishment clause. ${ }^{21}$ In his dissent, Justice Scalia derided the majority's reliance on legislative intentions. After an extensive analysis of the legislative history, which Justice Scalia found conformed to the requirements set forth in past Supreme Court precedents that legislation have soine secular purpose, ${ }^{22}$ le argued that the legislative history was irrelevant. If a legislator asserted that he had accidentally pressed the "yes" button instead of the "no" button during a vote, and if it was clear that this mistake passed a law that otherwise would have been defeated, then this aspect of "legislative history" would not invalidate the law. A showing of non-intention is irrelevant to the constitutional validity of the law. The same would be true if legislative history indicated that a legislator liad been influenced by a deal to gain support for an unrelated bill, a desire to get a session over with so he could go fishing, or any other factor irrelevant to the merits of the proposed Act. Therefore, Scalia argued, the fact that a legislator might have been influenced by his religious beliefs also should be irrelevant. ${ }^{23}$

\section{B. Separation of Powers as a Justification for Prohibiting the Use of Legislative History}

Unique ainong his brethren on the Supreme Court, Justice Scalia lias asserted that there is a constitutional reason for ignoring legislative history. The Constitution itself himits the legislature to a specific role: Congress may pass laws on topics listed in the Constitution, ${ }^{24}$ and it must accomplisli the legislative task according to the method set forth in

21. 482 U.S. 579, $591-94$ (1987) (Brennan, J., Inajority). The result was based in part on the finding that the legislature intended for the particular legislation to grant approval to one branch of evangelical Christianity. See id.

22. Id. at 619-36 (dissenting).

23. Id. at 636-37. However, it is central to a wide range of constitutional cases and statutory cases that even where a particular action was totally discretionary in the governmental actor, it could not be undertaken for a "wrong" motive. Justice Scalia imphicitly endorsed this view in J.A. Croson Co. v. City of Richmond, $109 \mathrm{~S}$. Ct. 706, 735 (1989) (concurring), where he agreed that although a city may hire any contractor or no contractor, it may not choose one contractor over another on the basis of skin color.

24. U.S. CoNST. art. I, $\S 8, \mathrm{cl} .8$. He also would presumably recognize the rights of Congress to act on inpeachments, and on proeedural matters to the extent these are enumerated in $i d$. art. I, $\S 2$, cl. 5 (choice of Speaker of the House); id. $\S 3$, cl. 5 (choice of Senate officers); id. $\S 4, \mathrm{cl}$. 1 (limited power on regnlation of elections of members); id. $\S 5$ (determination of internal rules, proeedural rules for debate, and adjournment). 
the Constitution. ${ }^{25}$ The creation of legislative history is not among the constitutional duties. ${ }^{26}$ Further, the process of creating statutes must include votes by both legislative branches on bills with identical wording and a presidential signature (or the override of a veto)-without this process, no legislation has been passed. ${ }^{27}$ Accordingly, the legislative history, which has not been subjected to review by the other house and the President, is not part of the law. To complete the circle, the Constitution limits the courts to considering "Cases ... arising under this Constitution, the Laws of the Umited States, and Treaties . . ."28 Courts have no jurisdiction to review controversies arising under a provision of legislative history. ${ }^{29}$

According to this theory, congressional intimations that courts should consider the legislative history of a statute may be outside the scope of congressional powers, and an unconstitutional attempt at congressional self-aggrandizement. ${ }^{30}$ Courts charged with enforcing article I of the Constitution and with the balancing of powers implicit in the con-

25. Id. art. I, $\S 7$.

26. But see U.S. CoNST. art. I, $\S 5$, cl. 3 ("Each House shall keep a Journal of its Proceedings, and from time to time publish the same, excepting such parts as may in their Judgment require secrecy ...."). Arguably, this provision makes the creation of a legislative history mandatory. The Supreme Court's only ruling on this clause allowed the legislative branches complete discretion on what must be imcluded in the journal. See Field v. Clark, 143 U.S. 649, 671 (1892) ("[W]hether bills, orders, resolutions, reports, and amendments shall be entered at large on the journal, or only referred to by their titles or by numbers; these and like matters were left to the discretion of the respective houses of Congress."). The House and Senate have indeed decided to make committee reports mandatory. See infra notes and text accompanying notes 68-71.

27. Puerto Rico v. Isla Petroleum Corp., 485 U.S. 494, 501 (1988) (majority) ("There is no text here ... to which the expressions of pre-emptive mtent in legislative history might attach. ... [U]nenacted approvals, behefs, and desires are not laws.").

28. U.S. CONST. art. III, $\S 6$. This might appear to preclude consideration of state law by a federal court. However, the Rules of Decision Act, 28 U.S.C. $\$ 1652$ (1982), states, "The laws of the several states, except where the Constitution or treaties of the United States or Acts of Congress otherwise require or provide shall be regarded as rules of decision in civil actions in the courts of the United States ...."

29. Center for Auto Safety v. Peck, 751 F.2d 1336, 1351 (D.C. Cir. 1985) (majority).

30. This theory raises the imteresting question of whether a statute mimicking the language of 28 U.S.C. $\$ 1652$, quoted at supra note 28 , but substituting "congressional legislative history" for "laws of the several states" would be constitutional. Conceivably, the Court's willfully ignoring legislative history might motivate Congress to pass such a statute.

The "Biden Condition" attached to the Senate's ratification of the INF treaty, 134 CoNG. REC. S6937 (daily ed. May 27, 1988), an attempt by the Senate to set forth a "Rule of Decision" for treaties, is an interesting example of the legislative branch directing the Executive's interpretation of a treaty. The Biden Amendment's constitutionality has been questioned, but the issue has not been hitigated, and probably cannot be, since no individual is likely to have standing to contest the interpretation of a Ballistic Missile treaty. But $c f$. United States v. Stuart, 109 S. Ct. 1183, $1196-98$ (1989) (concurring in the judgment), where Justice Scalia suggested that the Biden Condition was unconstitutional. See infra text accompanying notes 48-51. For views of the Biden Condition, see generally Symposium, Arms Control Treaty Reinterpretation, 137 U. PA. L. REV. 1351 (1989), especially the contributions of Abraham Sofaer, Treaty Interpretation: A Comment, in id. at 1437, and that of 
stitutional scheme, ${ }^{31}$ should not acquiesce to this kind of power play. Instead, as Justice Scalia argues, courts should read the statutes passed by Congress as the only congressional actions that have any effect on the outside world:

Respoudents press upon us an excerpt from the House Committee Report pertaining to the 1985 reenactment .... If this language is to be controlling upon us, it must be either (1) an authoritative interpretation of what the 1980 statute meant, or (2) an authoritative interpretation of what the 1985 Congress intended. It cannot, of course, be the former, since it is the function of the courts and not the Legislature, much less a Committee of one House of the Legislature, to say what an enacted statute means. Nor can it reasonably be thought to be the latter-because it is not an explanation of any language that the 1985 Committee drafted, because on its face it accepts the 1980 meaning of the terms as subsisting, and because there is nothing whatever im the text or even the legislative history of the 1985 reenactment that Congress thought it was doing anything insofar as the present issue is concerned, exccpt reenacting and making permanent the 1980 legislation. ${ }^{32}$

Justice Scalia relates prudential (and constitutional or governmental) concerns to his theory of statutory interpretation: The Supreine Court should encourage the coordinate branches to function as prescribed by the Constitution. Since the Constitution mandates that the legislature express its intent through laws, not through committee reports, ${ }^{33}$ then giving any weight to pronouncements from reports will encourage "undemocratic" behavior, and reduce governmental accountability to the citizens. To discourage rehance on reports, Justice

Senator Joseph Biden and John Ritch, The Treaty Power: Upholding a Constitutional Partnership, in id. at 1529.

31. This is the view of the Office of Legal Policy: "There is a widely held view that judges must decide statutory cases by determining how the original legislature would have wanted the statute to be applied .... This view represents an abdication of the proper judicial role in deciding a statutory case or controversy ... ." OFFICE OF LEGAL POLICY, U.S. DEP'T OF JUSTICE, USING AND MISUSing Legislative History: A RE-eValuation of the Status of Legislative History in STATUTORY INTERPRETATION 40-41 (1989).

Justice Scalia has conceded the lack of textual support in the Constitution for the concept of separation of powers: "[T]he principle of separation of powers is found only in the structure of the [Constitution,] which successively describes where the legislative, executive, and judicial powers shall reside. One should not think, however, that the principle was any less iniportant to the federal franiers." Scalia, The Doctrine of Standing as an Essential Element of the Separation of Powers, 17 SUFFOLK U. L. REV. 881, 881 (1983) (footnote omitted).

32. Pierce v. Underwood, 487 U.S. 552, 566-67 (1988) (n1ajority). Interestingly, this case involved the 1985 aniendments to the Equal Access to Justice Act, the same provision in dispute in Hirschey v. Federal Energy Regulatory Conım'n, 777 F.2d 1 (D.C. Cir. 1985). See supra notes 9-10 and accompanying text. This argument presumes that the legislative history of a re-enactnient has less iniportance than that of the original enactment.

33. U.S. CoNST. art. I, $\S 7$. 
Scalia believes the Court slould refuse to consider the extra-legislative statements in interpretimg statutes. ${ }^{34}$

\section{Legislative History in the Interpretation of Very Old Statutes}

A large portion of the Supreme Court's caseload consists of interpreting extremely old statutes. For example, the Civil Riglits Act of 1870 and the Slierman Act, botli over a hundred years old, continue to generate substantial hitigation. Some Justices and commentators have suggested that it may be especially important to examine legislative history when dealing witl a very old statute because words are more likely to have clianged in meaning with the passage of time..$^{35}$

Justice Scalia presented his theory of interpreting old statutes in $K$ Mart Corp. v. Cartier, Inc., ${ }^{36}$ a case involving the 1930 Tariff Act. ${ }^{37}$ Agam, he maintained the Court sliould have imterpreted the language Congress used, not tried to determine what Congress meant:

The principle of our democratic system is not that each legislature enacts a purpose, imdependent of the language in a statute, which the courts must perpetuate, assuring that it is fully achieved but never overshot by expanding or ignoring the statutory language as changing circumstances require. To the contrary, it seems to me the prerogative of each currently elected Congress to allow those laws which change has rendered nugatory to die ... and to allow those laws whose effects have been expanded by change to remain alive if it favors the new effects. ${ }^{38}$

Thus, Justice Scalia does not regard legislative history as a necessary consideration, even when the statute clearly has clianged meaning over the years. What matters is not wliat the authors of the statute intended but rather what the current Congress probably believes the statute to mean,

34. In Thompson v. Thompson, 484 U.S. 174, $191-92$ (1988) (concurring in the judgment), Justice Scalia remarked:

One must wonder, however, whether the good produced by a judicial rule that accommodates this remote possibility is outweighed by its adverse effects. An enactment by implication cannot rcalistically be regarded as the product of the difficult lawmaking process our Constitution has prescribed. Committee reports, floor speeches, aud even colloquies between Congressmen ... are frail substitutes for bicameral vote upon the text of a law and its presentment to the President.

Id. at 191-92. For further discussion of these arguments, see Eskridge, Public Values in Statutory Interpretation, 137 U. PA. L. REv. 1007, 1076-79 (1989).

35. See, e.g., Monroe v. Pape, 365 U.S. 167, 172-83 (1961) (Douglas, J., majority) (extensivc examination of legislative history of § 1983); Ziegler, A Reassessment of the Younger Doctrine in Light of the Legislative History of Reconstruction, 1983 DuKE L.J. 987, 990-91 (same).

36. 486 U.S. 281, 323-25 (1988) (concurring im part, dissenting in part).

37. Tariff Act of 1930, Pub. L. No. 46-361, 46 Stat. 590, 741 (codified at amended at 19 U.S.C. $\S 1526(1988))$.

38. $K$ Mart, 486 U.S. at 325. 
when it decides not to repeal or revise them. ${ }^{39}$ For Justice Scalia, originalism is always imappropriate in interpreting statutes.

\section{Legislative History in Treaty Interpretation}

Treaties present a special obstacle to a Justice wlo hopes to divine the intent of a document's creator. Whose intent matters? A treaty has multiple legislative histories: the histories developed by the signatories to the treaty and the history accompanying Senate ratification. ${ }^{40}$ For Justice Scalia, the possibility of multiple histories is another reason to avoid legislative history altogetler.

Justice Scalia found reason to avoid consultation of the legislative history of a treaty in his first Supreme Court decision, O'Connor v. United States, in which he ruled in favor of the government's interpretation of a treaty affecting U.S. income taxation. ${ }^{41}$ In explaming the Court's decision, Justice Scalia stated: "While the Claims Court may liave been correct that the negotiating history does not favor the Government's position sufficiently to overcome what that court regarded as a plain textual meaning in favor of the taxpayers, it certainly does not favor the taxpayers' position sufficiently to affect our view of the text."42

Scalia expounded his views on the value of using treaty history at greater length in Chan v. Korean Air Lines, Ltd., a case arismg from the 1983 destruction of a Korean Air Lines aircraft by a Soviet missile. ${ }^{43}$ The airline souglit to invoke a provision in the Warsaw Convention (as modified by a later treaty) that limited its liability to $\$ 75,000$ per passenger. The airline liad printed the liability limitation on tickets in eightpoint type, significantly smaller than the ten-point type required by the treaty. The issue for the Court was wliether this violation invalidated the hability himitation. Liability depended on which of two facially inconsistent passages of the treaty were to be given force. Justice Scalia refused to examine the treaty's history, dismissing the Solicitor General's and the Petitioners' attempts by noting that they 'seek to explain the variance between Section I and Sections II and III (as well as the clear text of Article 3) as a drafting error, and lead us througl the labyrinth of the Convention's drafting history in an effort to establish this point."44 Jus-

39. This approach makes the circular assumption that the current Congress decided not to repeal or revise on the basis of what it read in the words of the statute, not on the basis of the statute's meaning at the time it was written.

40. If the other nation signing the treaty also created a legislative history, there conceivably could be a third source.

41. O'Connor v. United States, 479 U.S. 27 (1986) (majority).

42. Id. at 35.

43. 109 S. Ct. 1676 (1989) (majority).

44. Id. at 1683 . 
tice Scalia refuted the petitioners' argument by constructing a concededly hypothetical alternative treaty purpose, which proved that the treaty as written might not have been irrational. The hypothetical legislative intent leads to an outcome inconsistent with the legislative history, so Justice Scalia iguores the legislative history, in favor of "the text." Unsurprisingly, the opmion finds the text sufficiently clear to conclude there should be no penalty against the airline.

Justice Scahia's harshest words on the use of treaty history appear in his concurring opmion in United States v. Stuart. ${ }^{45}$ The issue in that case was whether a tax treaty with Canada allowed the Internal Revenue Service (IRS) to supply information to the Canadian tax authority even though that agency was commencing a criminal investigation. This presented a problem because the IRS is forbidden by statute from issuing a summons to further a criminal investigation of a United States taxpayer. ${ }^{46}$ Justice Brennan's inajority opinion held that the treaty's plain language allowed information disclosure, and the legislative history developed in the Umited States Senate ratification hearings of the treaty corroborated this understanding. Although Justice Scalia agreed with the Court's conclusion, he took exception to its reliance, even for corroboration, on the Senate legislative history. Asserting first that " $[t]$ he use of such materials is unprecedented," Justice Scalia then explains why those materials should not be consulted: "Using preratification Senate materials ... is rather like determining tle meaning of a bilateral contract between two corporations on the basis of what the Board of Directors of one of them thought it meant when authorizing tlie Chief Executive Officer to conclude it." $47 \mathrm{He}$ further noted that the Suprenie Court previously refused to give effect to explicit conditions of ratification of a treaty, and in Scaha's view conditions or stipulations in a committee report should receive no more respect than resolutions passed by the full Senate.

At the end of the concurrence, Justice Scaha explains his concern is not so much witli the case at hand (wliere, after all, he concurs in the

\footnotetext{
45. 109 S. Ct. 1183,1193 (1989).

46. 26 U.S.C. $\$ 7602$ (c) (1988).

47. Stuart, $109 \mathrm{~S}$. Ct. at 1195 . Justice Brennan replies:

[T] he better comparison is to a meeting of the Board whose minutes and position papers the other corporation's Board and Chief Executive Officer are invited to peruse. It is hornbook contract law that the proper construction of an agreement is that given by one of the parties when "that party had no reason to know of any different meaning attached by the other, and the other had reason to know the meaning attached by the first party."
}

Id. at 1192 n.7 (quoting Restatement (SECOND) OF Contracts $§ 201(2)(b)$ (1981)). Justice Brennan also might have noted that in Texaco v. Pennzoil, 729 S.W.2d 768 (Tex. App. 1987), cert. denied, 485 U.S. 994 (1988), the deliberations of the board of directors of one corporation were considered to be relevant in determining whether a contract had been formed. Id. at 791 . 
judgment) as with unrelated issues pending in other arenas. In particular, he names a then-pending controversy over the Senate's interpretation of the Anti-Ballistic Missiles Treaty ${ }^{48}$ (ABM treaty), and two cases recently decided by the District Court for the District of Columbia. ${ }^{49}$ These controversies all hinged on whether the Executive branch may be bound to the interpretation of a treaty that it expounded in ratification hearings before the Senate. Justice Scalia then goes far out of his way to issue an advisory opinion to the administration on how he would rule on this issue:

[T] he Government conceded that "authoritative Executive branch representations concerning the meaning of a Treaty which form part of the basis upon which the Senate gives advice and consent are entitled to be accorded binding weight as a matter of domestic constitutional law, and the Executive branch fully accepts that it is bound by such statements." It is not clear that this latest position taken by the Government in the District Court is correct, or would even be the position taken by the Solicitor General. 50

Thus, Justice Scalia announced, soinewhat gratuitously, that in his view the Executive Branch is not bound by any aspect of the legislative history of a treaty, not even the part that it contributed. This passage clearly is addressed to a "Case ... or controversy" not before the Court, and reads suspiciously like an advisory opinion, which the Supreme Court is expressly forbidden from given. ${ }^{51}$ Justice Scalia apparently either decided he could not wait until the controversy about the ABM Treaty reached the Supreine Court, or feared that the treaty was by its nature nonjusticiable and thus would never reach his chambers. In any event, Justice Scalia could not resist the teinptation to inake known his views.

\section{E. In Favor of Legislative History}

Despite Justice Scaha's arguments, courts liave nany compelling reasons to analyze legislative history. First of all, since tlie statutes under

48. Stuart, 109 S. Ct. at 1196-97 (citing Washington Post, Feb. 6, Feb. 17, and March 19, 1988).

49. Id. (citing Rainbow Navigation, Inc. v. Department of Navy, 699 F. Supp. 339 (D.D.C. 1988), and Rainbow Navigation, Inc. v. Department of Navy, 686 F. Supp. 354 (D.D.C. 1988)). Justice Scalia had ruled on another aspect of the same dispute prior to his appointment to the Supreine Court. Rainbow Navigation, Inc. v. Department of Navy, 783 F.2d 1072 (D.C. Cir. 1986).

50. Id. at 1197 (citation oinitted).

51. U.S. CoNST. art. III, $\S 2$, cl. 2.

As Justice Scalia has noted in another context

[G]iving a court authority to take action directed, not to the resolution of the dispute before it, but to the generation and management of other disputes, is, if not unconstitutional, at least so out of accord with age-old practices that surely it should not be assumed unless it has been clearly conferred.

Hoffman-La Roche, Inc. v. Sperling, 110 S. Ct. 482, 489 (1989) (dissenting). 
interpretation are enacted by Congress, Congress is the obvious place to turn to determine what, if anything, the statutory words mean. ${ }^{52}$ Justice Scalia has proposed that courts ignore Congress's own explanation of the words it has chosen in favor of inore general defimitional sources, such as a dictionary or a thesaurus. ${ }^{53}$ Yet such sources will shed light on congressional intent only if Congress anticipated the question and rehed on the same source as the courts.

More significantly, Justice Scalia's discussions frequently suggest that the Court often faces a choice between relying on legislative history or commonly accepted principles of adjudication. However, the choice before the Court could be described, equally accurately, as between following the congressional judgment on a particular issue or following soine other standard in making a decision. Relying on an adminstrative agency's interpretation-an approach Justice Scalia favors ${ }^{54}$-is no more "neutral" than reliance on legislative history. And to the extent agency interpretation replaces the judgment of elected officials with the judginent of civil servants, it is less democratic. Further, the creation of legislative history is sanctioned by the Constitution ${ }^{55}$ whereas decisionmaking through an administrative process is not. ${ }^{56}$

A judge committed to avoiding legislative history frequently must rely on other abstract principles to decide a case. Justice Scalia frequently uses a pragmatic principle: He ehininates possible interpretations based on what a particular word "cannot rationally . . . mean." 57 But obviously, this type of judgment substitutes the legislative meaning

52. Stanley Fish has argued that all statutes are inherently ambiguous, because words have no meaning outside of the interpretative community where they were created. See S. FiSH, DoING What Comes Naturaliy: Change, Rhetoric, and the Practice in Literary and Legal STUDIES 123 (1988) ("[R]ules, in law or anywhere else, do not stand in an independent relationship to a field of action on which they can simply be inposed . . . ."). Without taking this extreme position, it is unarguable that a statute of general application, no natter how carefully drafted, will give rise to some ambiguities when interpreted in a new context.

53. In John Doe Agency v. John Doe Corp., 110 S. Ct. 471,479 (1989) (dissenting), the thesaurus consulted by Justice Scalia led to the opposite conclusion of the dictionary consulted by Justice Blackmun. Compare id. at 480 with id. at 476 (Blackmun, J., majority). A definition from legislative history presumably could have settled the dispute in the way that Congress intended; Justice Blackmun at least noted that there was no helpful legislative history on the issue in question.

54. Scalia, Judicial Deference to Administrative Interpretation of Law, 1989 DuKE L.J. 511.

55. U.S. ConST. art. I, $\S 5, \mathrm{cl} .3$ ("Each House shall keep a Journal of its Proceedings and from time to time publish the same, excepting such Parts as may in their Judgment require Secrecy .... .").

56. See generally P. STRAuSS, AN INTROduction to AdMINISTRATIVE Justice IN THE UNITED STATES 12 (1989) ("[T]he Constitution ... does not define the government itself. That is to say, it does not define the bureaucracy, the specialist institutions that carry out the specific tasks of public affairs.").

57. Green v. Bock Laundry Machine Co., 109 S. Ct. 1981, 1994 (1989) (concurring in the judgment). Three dissenting Supreme Court justices, however, found a version of the "irrational" meaning the proper one. 
with one created by an unelected judge whose constitutional role is limited to deciding cases, not rewriting laws to fit his own sense of rationality. ${ }^{58}$ From the point of view of fidelity to either the Constitution or the principle of deinocracy, then, reliance on legislative history is superior to reliance on other sources.

Justice Scahia's prudential reasons for avoiding legislative history are no more convincing. It may be true that the Court sliould not encourage Congress to circumvent the legislative process by passing vague laws and then relying on precise legislative history to direct the Executive Branch enforcing the laws. However, Professors Glicksman and Shapiro lave argued that Executive refusal to follow clearly expressed congressional intent in legislative histories forces Congress to make the opposite mistake: to legislate with too much detail. ${ }^{59}$ For example, the perceived need to legislate with too much specificity in the environmental field ${ }^{60}$ has forced Congress to make scientific judgments, relying to a greater extent on its staff in areas in which it often lacks expertise. Because Congress almost always acts prospectively, it is poorly equipped to allow exceptions to statutes of general application, even where a fundamental sense of justice might require an exception. A Member of Congress might be inore comfortable explaining her intent in a committee report rather than writing a more specific bill if she reasonably believed the interpreters of the statute would look to the committee report for guidance, and follow it, absent some unforeseeable but compelling reason to act otherwise. ${ }^{61}$

Senator Biden has asserted that a long-standing, negotiated balance of power between the Executive and Legislative branches makes less formal commumications, such as Senate reports, especially crucial in the area of Senate influence over foreigu policy ${ }^{62}$ and treaty interpretation. ${ }^{63}$ Because foreign policy actions frequently require greater statutory delegations to the Executive Branch (otherwise, the President would be unable to react to rapidly changing events, or to negotiate treaties) the Senate has in the past coupled delegation with various mechanisms for

58. In other contexts, Justice Scalia generally espouses a narrow role for the Judiciary. See, e.g., Honig v. Doe, 484 U.S. 305, 332-42 (1988) (dissenting) (advocating narrower understanding of judicial "case or controversy"); Hoffman-La Roche, Inc., v. Sperling, 110 S. Ct. 482, 488 (1989) (arguing that courts have limited power to notify potential plaintiffs of claims).

59. Shapiro \& Glicksman, Congress, the Supreme Court, and the Quiet Revolution in Administrative Law, 1988 DUKE L.J. 819, 840-42.

60. This need grew from a perception that the Environmental Protection Agency was refusing to perform its congressionally mandated role in promulgating regulations. $I d$. at 825-28.

61. Judge Scalia explicitly rebuffed an attempt to do this in Center for Auto Safety v. Peek, 751 F.2d 1336, 1351 (D.C. Cir. 1985) (majority).

62. Biden, Who Needs the Legislative Veto?, 35 SyracuSE L. REv. 685, 693-701 (1984).

63. Biden \& Ritch, supra note 30, at 1533-36. 
continuous oversight, not through additional statutes but through resolutions, committee investigations, and committee reports. Since the Supreme Court declared the legislative veto unconstitutional in Immigration and Naturalization Service v. Chadha, ${ }^{64}$ such mechanisms have little binding force. Senator Biden claims that President Reagan's decision to ignore a joint resolution requestimg withdrawal of troops from Lebanon led to the loss of American hives. ${ }^{65}$ By similar reasoning, allowing the Executive to ignore representations it made to Congress when it interprets treaties would "threaten[ ] paralysis ... . since the Senate's only recourse would be to attach elaborate and numerous conditions to treaties in order to ensure that its understanding became an integral and explicit part of a treaty's ratification documents." 66

The recurrent argument that legislative history is created by nonlegislators and therefore inadmissible, is completely fallacious. All three branches of government commouly delegate the job of drafting written material to staff members. A Meinber of Congress may not have read the legislation she is voting, any more than she read the legislative history; this fact does not reduce the importance of either document to the nation. ${ }^{67}$ Moreover, the fact that a judicial clerk rather than a duly confirmed article III judge wrote a particular opmion does not niake it less binding on lower courts. Similarly, if the President accepts without reservation an aide's or an astrologer's recommendation that a bill be vetoed, and even signs the veto message proposed by the aide without reading it, the veto still would have legal force. ${ }^{68}$ What should count is not whio operates the word processor, but whether the proper elected official accepts responsibility for the words, according to proper procedures.

Finally, it is not the case that a Member of Congress may slip authoritative comments favoring special interest groups into legislative his-

64. INS v. Chadha, 462 U.S. 919 (1983). Significantly, Justice Scalia had long argued that the legislative veto was unconstitutional. Scalia, The Legislative Veto: A False Remedy for System Overload, Regulation, Nov./Dec. 1979, at 3; 1976 Bicentennial Institute-Oversight and Review of Agency Decisionmaking, 28 ADMIN. L. REV. 569, $685-89$ (1976) (remarks of Assistant Attorney General Antonin Scalia).

65. Biden, supra note 72, at 700 (citing H.R. 2915, 98th Cong., 1st Sess. $\$ 1013$ (1983) (urging troop withdrawals), and H.R. CoNF. REP. 563, 98th Cong., 1st Sess. (1983) (same).

66. Biden, supra note 30 , at 1539.

67. Anyone who has read both will admit, however, that committee reports are much more accessible than statutory language to the average reader. Because of that committee reports may be more likely to be read, by Members of Congress as well as by the general public.

68. Thus, the fact that President Reagan chose the moment for announcing his choice of Justice Kennedy's appointment on the basis of his astrologer's unreviewed recommendation did not render the appointment invalid, even though the Constitution grants responsibility for judicial nominations to the President and not the astrologer. See J. Quigley, "What Did JOAN SAx?" MY SEvEN Years as White House Astrologer to Nancy and Ronald Reagan 170-71 (1990). 
tory that otherwise would not have been acceptable to the legislature as a whole. Both the House and the Senate have rules governing the production of committee reports, mandating both the contents of a legislative history and the means by which it is produced. ${ }^{69}$ These rules require that cominittee records be kept openly and contain an adequate explanation of the congressional action under consideration, including cost estmrates, regulatory impact analysis, and other specific topics. ${ }^{70}$ Members of the coinmittees have an opportumity to publish concurring or dissenting views. ${ }^{71}$ Indeed, minority staff and staff of committee members closely montor the writing process, and tell their boss either to object to an offending provision contrary to the will of the committee, or to file views to the report, signalling the controversy to other Members. Thus, an uncontradicted statement in a legislative history could not appear unless no other committee mernber of the committee beheved it was important to contradict that statement. Further, the reports must be available to the full House and Senate, and any Mernber of Congress is free to raise questions on the floor with respect to the committee report, or to vote against a piece of legislation because she disagrees with the committee report, whether or not she supports the text of the proposed legislation. In other words, the congressional review of legislative history is not very different from the congressional review of legislation.

\section{CONSTITUTIONAL INTERPRETATION}

\section{A. Is the Constitution Different?}

At least since the time of Chief Justice Marshall,72 Supreme Court Justices and legal commentators frequently have argued that the rules for understanding and interpreting the Constitution differ from the rules for interpreting a statute. Because the words of the Constitution are generally immutable and the Constitution was created at a unique moment in American history, it should be treated differently from statutes regularly enacted at the will of Congress. For example, a court can fashion a remedy for violations of the Constitution, even in the absence of any explicit

69. Senate Manual Containing the Standing Rules, Laws, and Resolutions Affecting the Business of the United States Senate, S. Doc. No. 100-1 (1988), Standing Rule 26.10-11; Constitution, Jefferson's Manual and Rules of the House of Representatives, H.R. Doc. No. 100-218 (1988), Rule 11, cl.

2. For explanation of how Congress actually produces legislative history, see Costello, supra note 10.

70. Senate Standing Rule 26.11a-b; House Rule 11, cl. $2, \S 713 \mathrm{e}$.

71. Senate Rule 26.10c; House Rule 11, cl. 2, § 714.

72. McCullough v. Maryland, 17 U.S. (4 Wheat.) 316, 407 (1819) ("We inust never forget, that it is a Constitution we are interpreting."). 
grant of private remedy. ${ }^{73}$ On the other hand, Supreme Court opinions interpreting the Constitution should be accorded less stare decisis weight because they cannot be undone by the legislature if erroneous. ${ }^{74}$ Finally, the Framers of the Constitution are inore distant from us in both time and worldview, and their concerns are more alien to us, than the understandings of the authors of virtually all statutes. Whether the original, historical meaning of the Constitution, as evidenced by views the Framers expressed outside of the text of the Constitution itself, should be consulted is a controversial issue. ${ }^{75}$

Justice Scalia, however, has rejected in one sense the notion that the Constitution is inherently different from a statute:

[T] Constitution, though it has an effect superior to other laws, is in its nature the sort of "law" that is the business of the courts-an enactment that has a fixed meaning ascertainable through the usual devices familiar to those learned in law. ${ }^{76}$

So, regardless of the reasons for considering the Constitution differently, for Justice Scalia it is in the end simply a document for a court to interpret. ${ }^{77}$

Justice Scalia's interpretive behef affects his constitutional rulings. For example, lie lield that where a statute precluded legal challenge to an

73. Bivens v. Six Unknown Named Officers, 403 U.S. 388 (1971). See generally E. CHEMERINSKY, FEDERAL JURISDICTION $451-70$ (1988) (summarizing current case law).

74. Justice Scalia endorses this view in Gathers v. South Carolina, 109 S. Ct. 2207, 2218 (1989) (dissenting).

75. The Office of Legal Policy has asserted:

In fact, the justifications for looking beyond the text are even weaker for statutes than for the Constitution. First, most statutes that are the subject of litigation are of relatively recent origin, and the original meaning of their language is the same as the contemporary meaning. Second, the legal rules in statutes are usually spelled out in greater detail than those in the Constitution. Third, the Coustitution specifies rules for the enactment of statutes that imply severe limits on the use of legislative history, but since these rules are obviously inapplicable to the Constitution itself, they are not directly relevant to constitutional interpretation.

OFFICE OF LEGAL POLICY, supra note 31, at 26 n.97. A complete refutation of this view is beyond the scope of this Note. However, the first justification is out of step with Justice Scalia's view of the interpretation of old statutes, see supra text aecompanying notes 35-38, and the second directly contradicts the Office of Legal Counsel's view that legislative history should not be used to fill gaps. Id. at 97-104. Finally, the Constitution also specifies rules for its own ratifieation, which on their own terms appear to preclude the consultation of secondary sources for constitutional interpretation. See infra text aecompanying notes 89-92.

76. Scalia, Originalism: The Lesser Evil, 57 U. CIN. L. REv. 849, 852 (1989). Curiously, though, the "nsual devices" Justice Scalia lists in the passages that follow include examination of "legislative history," and similar sources, which he precludes from consideration in statutory decisions.

77. In light of Justice Scaha's views of statutory interpretation, one might expect that "the usual devices" to which he refers include careful examination of the text, perhaps aided by a dictionary. But this turns out not to be the case. See, e.g., id. at 859 (citing THE FEDERALIST PAPERS, Blackstone's COMmentaries, and the Debates at the North Carolina State Ratifying Convention). 
agency's decision, it should be interpreted to preclude challenge on constitutional as well as statutory grounds:

The only respect in which a constitutional claim is necessarily more significant than any other kind of claim is that ... it can be asserted against the legislature itself, whereas a nonconstitutional claim ... cannot. That is an important distinction. ... But it has no relevance to the question whether, as between executive violations of statutes and executive violations of the Constitution - both of which are equally unlawful, and neither of which can be said, a priori, to be more harmful or more unfair to the plaintiff-one or the other category should be favored by a presumption against exclusion of judicial review. ${ }^{78}$

The special concerns about violations of constitutional rights that motivated Chief Justice John Marshall in McCullough carry no weight against the asserted right of Congress to limit the judiciary's jurisdiction in any way that it chooses (even though the jurisdictional limitation is far from clear).

Thus, if a statute and the Constitution do not conflict, Justice Scalia would interpret both according to the same rules. Based on the rules he uses for interpreting statutes, then, one would expect that Justice Scalia would rely on the text of the Constitution as the sole source of its meaning.

These expectations, however, would be disappointed. Justice Scalia's views on constitutional interpretation, unlike his position on statutory interpretation, resemble the views of other conservative judges. $\mathrm{He}$ is an originahist who seeks to interpret the Constitution as the Framers would have understood it. ${ }^{79}$ This view is not absolute-for exanple, Justice Scaha does not advocate overturning longstanding precedents simply because they do not accord with some of the founders' behefs on a particular issue. ${ }^{80}$ However, Justice Scalia's outlook informs his behefs and decisions in most areas. ${ }^{81}$ Where precedent has deviated in a substantial way from original intent, it should have limited apphication in

78. Webster v. Doe, 486 U.S. 592, 618 (1988) (dissenting).

In this case, Chief Justice Rehnquist's majority opinion reinstated a wrongful discharge action by a CIA einployee who had been fired because of his homosexuality. The plaintiff had argued that this action violated the fourteenth anendment. The nnajority's opinion argued that the statute forbidding challenges to $\mathrm{CIA}$ enployment decisions was inapplicable to a constitutional challenge. Because the decision reversed a district court's dismissal, the Supreme Court did not reach the inerits of the claim.

79. Scalia, supra note 76, at 852. Compare this position to that taken in Confirmation Hearings, supra note 7, at 48-49, where Justice Scalia refused to be pinned down to an originalist position, but conceded that he was "Inore inclined to the original ineaning than ... to a phrase like "hiving Constitution." "

80. Scalia's favorite example of this is the possibility that a historian might discover that Marbury was incorrectly decided. Scalia, supra note 76 , at 861 .

81. This view is less strict with regard to some parts of the Bill of Rights. See, e.g., Jones v. Thomas, 109 S. Ct. 2522, 2529 (1989) (dissenting) (double jeopardy); Grifin v. Wisconsin, 483 U.S. 
future cases: this precedent is "suspect" if the Court has an opportunity to reconsider the area. ${ }^{82}$ Justice Scalia uses a variety of sources to determine "original intent," principally the Records of the Constitutional Convention, the Federahist Papers, pre-Constitutional case law, and Samuel Johnson's Dictionary. Even sources not coinposed by the Framers are introduced in order to provide evidence of what they beheved words or constitutional clauses to inean..$^{83}$

\section{B. The Problems with Constitutional History}

The probleins of the unrehability of the record of the constitutional "legislative history" 84 are greater than they are with recently enacted statues. After all, the Convention did not publish a record of proceedings, and nost of the currently available record was created froin James Madison's notes, which were not published until 1840, and have long been considered to be of uncertain accuracy. ${ }^{85}$ There is little evidence that the Framers expected courts to use their notes and debates as guides to legal interpretation. ${ }^{86}$

In soine respects, the Constitution also may be understood as a treaty between separate sovereign states. The individual states ratified

868 (1987) (majority) (probable cause); Richardson v. Marsh, 481 U.S. 200 (1987) (majority) (confrontation clause); Cruz v. New York, 481 U.S. 186 (1987) (majority) (same).

82. Scalia, supra note 76 , at 854 .

83. See infra notes 84 and 89.

84. Justice Scalia relies on Farrand's Notes From the Constitutional Convention in Honig v. Doe, 484 U.S. 305, 341 (1988) (dissenting) (meaning of "Case or controversy"); and Sun Oil Company v. Wortman, 486 U.S. 717, 723 (1988) (majority) (full faith and credit clause); and Morgan v. United States, 801 F.2d 445, 447 (D.C. Cir. 1986) (majority) (art. I, § 5, cl. 1, which states: "Each House shall be the Judge of the Elections, Returns and Qualifications of its Members.").

In another group of cases, he casts a wider net, using a variety of secondary sources to determine the common meaning of language used in the Constitution. Brower v. County of Inyo, $109 \mathrm{~S}$. Ct. 1378 (1989) (majority) (analysis of 1760's Writs of Assistance Case to determine meaning of "Search and Seizure"); Mistretta v. United States, 109 S. Ct. 647, 679 (1989) (dissenting) (Locke's SECOND TREATISE on importance of separation of powers); Coy v. Iowa, 487 U.S. 1012, 1014-19 (1988) (majority) (New Testament and Shakespeare used to explicate Confrontation Clause); Morrison v. Olson, 487 U.S. 654, 719 (dissenting) (Johnson's dictionary on meaning of constitutional term "inferior").

85. See generally Hutson, The Creation of the Constitution: The Integrity of the Documentary Record, 65 TEX. L. REv. 1, 24-33 (1986). Hutson argues that Madison's published notes are an accurate rendition of what he transcribed in 1787 , but "they are far from a verbatim account of what was said in the Convention." Id. at 35. Less complete versions of the Records of the Constitutional Convention were published as early as 1819. Id. at 2, 6-12.

86. Cf. Powell, The Original Understanding of Original Intent, 99 HaRv. L. Rev 885, 887 (1985). For a strident but unconvincing opposing argument, see Berger, The Founders' ViewsAccording to Jefferson Powell, 67 Tex. L. REv. 1033 (1989). 
the document in the same manner that nations would ratify a treaty. ${ }^{87}$ As a result of the common requirement of ratification, many of the justifications for ignoring the legislative history of treaties also apply to constitutional materials. The state ratifying conventions created separate "legislative histories" froin the national Convention. And smce nine state ratifications were necessary before the Constitution would have legal effect, ${ }^{88}$ Justice Scalia's reasons for rejecting the legislative history of treaties should apply with greater force to the Constitution.

Justice Scahia's occasional reliance on The Federalist Papers ${ }^{89}$ is especially iromic because they were not written or pubhished until after the Constitution had taken effect.90 Those writings were intended to influence the New York Ratification. Convention, but since New York was the tenth state to ratify, its ratification had no legal effect. ${ }^{91}$ Thus, the Federalist Papers resemble the after-the-fact legislative history Justice Scalia excoriated in Hirschey and Pierce v. Underwood. ${ }^{92}$ Another problem affecting both the Federalist Papers and all other contemporaneous

87. The Articles of Confederation "created not a national government, in any modern sense, but 'a firm league of friendship.' " Kay, The Illegality of the Constitution, 4 CONST. COMMENTARY 57, 62 (1986) (citing ARTICLES OF CONFEDERATION art. II). The states were not simply approving a resolution in conformance with their powers under the Articles of Confederation. Id. at 67-70.

88. U.S. CoNST. art. VII.

89. See, eg., Tyler Pipe Indus. v. Washington Dep't of Revenues, 483 U.S. 232, 264 (1987) (concurring in part and dissenting in part) (meaning of Commerce Clause); Morrison v. Olson, 487 U.S. 654, 697 (1988) (dissenting) (separation of powers); Young v. United States ex rel. Vuitton et Fils, 481 U.S. 787, 824 (1987) (concurring) (same); Mistretta v. United States, 109 S. Ct. 647, 682 (1989) (dissenting) (same).

Inexplicably, he also turns to The Federalist Papers in City of Richmond v. J.A. Croson \& Co., $109 \mathrm{~S}$. Ct. 709, 735 (1989) (concurring), a case where the only relevant constitutional provision was the fourteenth amendment. Justice Scalia approvingly quotes Madison's view that in a smaller rather than a larger community, the majority will be more likely to be able to oppress those who disagree with it. This argunient is uncharacteristically sloppy. First, Madison's views on the dangers of oppression of a minority referred to individuals who differed in political, not racial characteristics. Since Scalia has argued that the discrimination here is espeeially invidious because it is racial, Madison has nothing to say. More importantly, though, Madison's theory of federalism, and of the balancing of local, state, and federal interests, is coinpletely irrelevant. If Madison was advocating granting the federal judiciary power to review local governmental decisions, his view was not mcorporated into the final Constitution. All of the arguments presented in Croson concern the fourteenth amendnent, enacted in 1870, and without the benefit of Madison's draftsmanship. Since Scalia does not (and cannot) argue that the fourteenth amendment was part of a plan to fulfill Madison's vision of the federal government in the states, the quotation has no persuasive power in relation to the issue the Court faces.

90. See U.S. CONST. art. VII (Constitution becoines effective upon ratification by nine states).

91. Of course, the ratifications by the final four states had tremendous practical effects. If New York had not approved of the Constitution, the United States imight well have fallen apart. It would be very surprising if any New York court would accept the Constitution as legally binding, if that state had not ratified it. However, Justice Scalia applies formalistic standards to the use of legislative history in statutory contexts; if we consider the Constitution to be a statute, its interpretative inaterials should receive the same trcatment.

92. See supra text acconpanying note 32 . 
constitutional records is that they were unavailable to almost all of the states ratifying the Constitution, since they were published late in the ratifying process. In this respect, they resemble the legislative history associated with a treaty that Justice Scalia abhors using. ${ }^{93}$

Finally, the Federalist Papers arguably are more comparable to letters by a Congressman to his constituents than to committee reports. Garry Wills has argued persuasively that Madison occasionally mistepresented the Constitution to make it appear less threatening to its opponents or closer to Madison's preferred form of government. ${ }^{94}$

The most venerable argument opposing attempts to ascertain the Framers' intent is that they were aware they were writing a document that would last a very long time, and they intentionally chose language that could be interpreted flexibly. ${ }^{95}$ A related argument is that the Framers did not expect their documentary records to be consulted, thus to do so violates their intention. ${ }^{96}$ The fact that the Framers made no attempt to pubhish the Conventions records until much later and published the Federalist Papers anonymously contrasts with the practices of contemporary legislators, who require themselves to distribute publicly complete legislative histories to the general public, generally within seven working days. ${ }^{97}$

\section{EfFect of Justice Scalia's Rules for Balance of Power}

By now, it should be clear that Justice Scalia's originalism depends heavily on secondary sources to interpret the Constitution's provisions, but he iguores both secondary sources and congressional intent in interpreting statutes. The inconsistency is most apparent in the cases discussing separation of powers, where Justice Scalia cannot be a textualist simce he has no text. In other words, the text of Justice Scalia's Constitution is larger than the official text in the United States Code-it incorporates the Federalist Papers and the Documentary History of the Constitutional Convention, among other documents-whereas his book of statutes is precisely the same size.

Why this inconsistency? Curiously, the originalist approach to constitutional decisions has the same effect on the balance of powers as the

93. See supra text accompanying notes $42-51$.

94. See G. Wills, Explaining America: The Federalist 169-75, 267 (1981); see also Powell, Rules for Originalists, 73 VA. L. REv. 659, 687 (1987) (noting that the questions on the Federalists' sincerity limits their utility as legislative history).

95. See, e.g., Bickel, The Original Understanding and the Segregation Decision, 69 HARV. L. REV. 1, 63 (1955).

96. Powell, supra note 86 , at 887.

97. See generally Hutson, supra note 85 , at 2; Senate Standing Rule $26.10 \mathrm{~b}$ (seven working days); House Rule XI, cl. 2, § 713b (same). 
textualist approach to statutory decisions, ${ }^{98}$ at least in terms of the power of the legislature. In the simplest formulation, both rules reduce the legislature's power.

\section{A. The Separation of Powers Decisions}

Justice Scalia's views on the respective rights and powers of different branches of the government are forcefully stated, controversial, and may be the area of his greatest intellectual contribution. This Note analyses those decisions because they reveal Justice Scalia's metlod and the political conclusions that follow from his decision to consult secondary sources in constitutional imterpretation. ${ }^{99}$

If the Constitution is the same as a statute, as Justice Scalia suggests, then determining that a legislative enactment is unconstitutional based on "separation of powers" is problematic because neither the words nor concept of judicial review of legislation for separation of powers problems appear anywhere in the text of the Constitution. ${ }^{100}$ The Constitution defines three separate duties: the Legislative, the Executive, and the Judicial. In some areas, the enumerated powers of the three branches overlap. ${ }^{101}$

To Justice Scahia, the fact that there is no specific mention of separation of powers in the Constitution does not signify there is no basis for judicial decisions on issues involving separation of powers. ${ }^{102}$ Instead, he behieves that the Supreme Court has a duty to police the balance of pow-

98. Cf. Sunstein, Interpreting Statutes in the Regulatory State, 103 HARV. L. REV. 405, 430 n.91 (1989) ("The combination of textualism, disregard of legislative history, and the Chevron principle ... would produce a dramatic increase in the executive's power to make law.").

99. For a list of Justice Scalia's cases analyzing secondary constitutional source, see supra notes 84 and 89.

100. See Scalia, supra note 31 , at 881 ("[W] as a model for modern jndicial opimions, the principle of separation of powers is found only im the structure of the [Constitntion.]').

101. Compare U.S. CoNST. art. I, $\S 8$, cl. 12 (granting legislature the power "to raise and support armies") with id. art. II, $\$ 2$ ("The President shall be Commander in Chief of the Army and Navy"). The power to make binding treaties and to place Justices and other officials in office are, of course, joint responsibilities of the Executive and the legislative branches.

102. In Morrison y. Olson, Scalia noted that the Massachusetts Constitution contains explicit rules on separation of powers. Professor Casper has found that the Constitution did consider adopting a similar ineasure for the Umited States Constitution, but did not. Casper, An Essay in Separation of Powers: Some Early Versions and Practices, 30 WM \& MARY L. REV. 211, 221 (1989). In a statutory context, Scalia might have assumed that leaving a provision out precluded the judiciary from using its terms to decide cases. Cf. Confirmation Hearings, supra note 9, at 75, where Senator Heflin quoted an earlier speech by Justice Scalia where he stated that the strongest forın of legislative history is the case where a particular provision appeared on a draft and was later dropped by the full legislature. 
ers among the three branches in order to preserve the liberties of all Americans. ${ }^{103}$

But without any textual clues, how can the judiciary decide when a law or action violates separation of powers? The Supreme Court's body of precedent is rarely much help, since there were few cases on these issues before the 1970 s. ${ }^{104}$ The only textual clues are the three talismanic phrases: Legislative power, Executive power, and Judicial power. Consulting a dictionary - either a modern one or one in use in the $1780 \mathrm{~s}^{105}$ for insight into these terms is unlikely to answer the issue. A review of prominent recent separation of powers cases illustrates how Justice Scalia fashions an answer to this issue.

1. Synar. Justice Scalia's first major ruling on separation of powers decision was the per curiam decision in Synar v. United States, 106 in which a three-judge panel (including Judge Scalia) held the GrammRudman-Hollings Act ${ }^{107}$ included an unconstitutional delegation of executive powers to a legislative officer. ${ }^{108}$ As a result of the opinion, both congressional authority to make budget decisions according to Congress's wishes, and the authority of congressional agents was limited. The court found the law unconstitutional, not because it violated any provision of the Constitution, but because "it violates the fundamental

103. At his confirmation hearings, Justice Scalia asserted in his introductory remarks that the structural aspects of the Constitution were far more important for the preservation of a free democracy than were the Bill of Rights. He noted that the Soviet Constitution has some language similar to that in the Bill of Rights, but without procedural checks such language could not restrain the despotic tendencies of any government leader. Confirmation Hearings, supra note 9, at 32.

104. For a summary of the current incoherence of Supreme Court doctrine in separation of powers, see Pierce, Morrison v. Olsen [sic], Separation of Powers, and the Structure of Government, 1988 Sup. CT. REv. 1, 9-21.

105. Justice Scalia believes in the use of dictionaries contemporary with the statute in question. See, e.g., Morrison v. Olson, 487 U.S. 654, 719 (1988) (dissenting) (using 1785 edition of Johnson's Dictionary to define "inferior"); $c f$. Coy v. Iowa, 487 U.S. 1012, 1018 n.2 (1988) (majority) (explaining that citations to Shakespeare and a speech by President Eisenhower "illustrate the meaning of the [sixth amendinent] term "confrontation" "-although neither quotation uses that word).

106. 626 F. Supp. 1374 (D.D.C. 1986), aff'd sub nom. Bowsher v. Synar, 478 U.S. 714 (1986). Chief Justice Burger's inajority opinion generally accepted Judge Scalia's logic, and also quoted from a reference by Madison to Montesquieu, in The Federalist No. 47. 478 U.S. at 722.

107. Balanced Budget and Emergency Deficit Control Act of 1985, Pub. L. No. 99-177, 99 Stat. 1037 (1985).

Pursuant to the Act, $\S 274(a)(5), 2$ U.S.C. $\$ 922(a)(5)$, the case was tried by a three-judge panel including two judges from the District of the District of Columbia, and a third judge from the District of Columbia Circuit Court of Appeals. In part because of the academic nature of the per curiam opinion, many commentators assumed that Justice Scalia was its primary author. See, e.g., Wilson, Constraints of Power: The Constitutional Opinions of Judges Scalia, Bork, Posner, Easterbrook and Winter, 40 U. M1AMI L. REv. 1171, 1201 (1986) ("Scalia is rumored to have written most, if not all, of the unisgned, per curiam decision . . . .").

108. 626 F. Supp. at 1404. 
principal expressed by Montesquieu upon which the theory of separated powers rests." 109 Besides attributing the idea to Montesquieu, the Court buttresses it with an ambiguous quotation from Federalist No. 48. ${ }^{110}$ As further authority for this opinion's concededly unique theory of separation of powers, the decision included a lengthy citation to an article by a "respected scholar" who took an originalist approach to a different separation of powers question and relied lieavily on secondary sources.111

2. Young, and Morrison v. Olson. Justice Scaha's first Supreme Court opinion on separation of powers appears as a concurrence im Young v. United States ex rel. Vuitton et Fils. ${ }^{112}$ There, the issue was whether a district court had the power to appoint a special prosecutor to pursue a criminal contempt charge arismg from violation of a court-ordered civil injunction when the special prosecutor had previously represented the opposing party in the underlying civil action. Justice Brennan's majority opinion held that this practice should be stopped by use of the Supreme Court's supervisory powers, ${ }^{113}$ and Justice Blackmun's concurrence viewed the practice as a violation of the criminal defendant's right to due process. ${ }^{114}$ Only Justice Scalia understood the issue as a question of separation of powers: Could the typically Executive function of initiating a prosecution be left to an official appointed by the Judiciary? Justice Scalia begins with a discussion of Hamilton's Federalist No. 78, which states that the judiciary "has no influence over either the sword or the purse."115 Justice Scalia takes this authority, together with Hamilton's approving citation of Montesquieu to the effect that separating the Judiciary from the Legislative and Executive powers is necessary to secure liberty, and concludes that the judiciary has no inherent power to appoint a special prosecutor in any situation, regardless of the equities of a particular case. ${ }^{116}$

109. Id. at 1401 .

110. Id. at 1402 (quoting THE FEDERAL1ST No. 48, at 327 (J. Madison) (P. Ford ed. 1898)). The quoted portion is: "[N]one of [the branches] ought to possess, directly or indirectly, an overruling influence over the others, in the admmstration of their respective powers." By itself, this passage equally supports the argument that the Supreme Court has no power to declare an act of Congress unconstitutional.

111. Id. at 1403-04 (citing Krattenmaker, Article III and Judicial Independence: Why the New Bankruptcy Courts Are Unconstitutional, 70 GEo. L.J. 297, 301-02, 311 (1981)).

112. 481 U.S. 787, 815 (1987) (concurring in the judgment).

113. Id. at 789 (Brennan, J., majority).

114. Id. at 814 (Blackmun, J., concurriug).

115. The Federalist No. 78, at 522-23 (J. Cooke ed. 1961).

116. Young, 481 U.S. at 818-19. 
Young foreshadows Scaha's lonely dissent in Morrison v. Olson, ${ }^{117}$ in which he argued that Congress may not delegate the power of appointing a special prosecutor to anyone other than an agent of the Executive. $\mathrm{He}$ began with a citation to the Massachusetts Constitution for the proposition that other political bodies writing constitutions when the United States Constitution was written believed in strong enforcement of separation of powers principles. To buttress the point that at least one framer of the federal Constitution also felt separation of powers was important, he cites several Federalist Papers. ${ }^{118}$ Justice Scalia notes that proposals for multiple Executives were rejected at the Constitutional Convention, as if that information makes the obvious point that there is one President seem inore important. Moving on to review of Congress's decision, he draws from another of Madison's Federalist Papers for the standard of review. ${ }^{119}$ Froin there, he returns to the small amount of constitutional text on Executive functions to give substance to the defimition: "In what other sense can one identify 'the executive power' that is supposed to be vested in the President ... except by reference to what has always and everywhere-if conducted by Government at all-been conducted never by the legislature, never by the courts, and always by the executive."120

Later in the opinion, Justice Scalia attempts to limit the ineaning of the term "inferior officer" of the United States (who may be appointed by the judiciary) ${ }^{121}$ by appealing to a 1785 dictionary definition. He concludes that the term ineans "subordinate,"122 in part because Hamilton defined it that way in Federalist No. 81. ${ }^{123}$ Then Justice Scaha returns to the Constitutional Convention debates to prove that some ineinbers thought inferior officers did not need to be inentioned because that power to appoint such offices is imphicit in the enumerated powers. This perspective, Justice Scalia asserts, proves that the inferior officers authorized could not be anyone important. Since he assumes that a special prosecu-

117. 487 U.S. 654, 697 (1988) (dissenting). In Morrison, Chief Justice Rehnquist's majority opinion upheld the Ethics in Government Act of 1978, inandating the appointment of special prosecutors to investigate alleged criminal activities by executive officials.

118. The FEderalists Nos. 47, 51 and 53 (cited at $i d$. 697-705). He later cites Hamilton's THE FEDERALIST No. 70, for the general view that the President has a inoral and a practical responsibility to the people of the nation. Id. at 729 .

119. Id. at 704-05. As he notes, this discussion is completely irrelevant, because the majority opinion used the same standard of review.

120. Id. This definition does not invalidate the office of the special prosecutor, since the appointment of special prosecutors has been left outside of the executive branch at other times.

121. U.S. CoNST. art. II, $\$ 2$, cl. 2.

122. Morrison, 487 U.S. at 719-21. Since the dictionary offers two definitions, and "subordinate" is the second, it would have been equally valid to assume that "inferior" meant "lower in . . . value or excellency." In that case, a special prosecutor would clearly be an inferior officer.

123. Id. at 720 ("In Federalist No. 81, Hamilton pauses to describe the 'inferior' courts authorized by Art. III as inferior in the sense that they are 'subordinate' to the Supreme Court."). 
tor would be someone very important to the founders, the appointinent of special prosecutors cannot be allowed. ${ }^{124}$ Unfortunately, this circuitous logic ends with a position that the first century of American judges would not have understood, since private, not executive, prosecution was the norm in the colonial period, and independent prosecutors were conlmon in the early days of the Republic. ${ }^{125}$

3. Mistretta. Justice Scalia's other important separation of powers dissent is Mistretta v. United States, in which the Court affirmed the constitutionality of the Umited States Sentencing Commission. ${ }^{126}$ The Commission included federal judges, and their recommendations on criminal sentences became law pursuant to the authorizing statute. Here, the problem for Scalia appeared to be excessive delegation of power. To denionstrate the issue mattered to the Framers, Justice Scalia pointed to a theoretical work written nearly a century before the Constitution, John Locke's Second Treatise of Government, which asserted that a legislature may make laws but not legislators. ${ }^{127} \mathrm{He}$ also considers the Framers' intentions in order to refute the majority's reading of Federalist No. 47.128 Again, although the Constitution nowhere forbids Congress fron delegating authority, Justice Scalia believes such a delegation is unconstitutional because an authority on which the Framers might have relied considered this delegation beyond the powers of the legislative brancl1. This logic prevents Congress fron deciding proper sentences for convicted criminals in the mauner that it close. Congress's power shrinks, and that of federal judges increases.

4. Eleventh Amendment: Pennsylvania v. Union Gas. In Pennsylvania v. Union Gas, Justice Scalia dissented in part froin the Court's holding that the Superfund legislation allowed Uinon Gas to file a clann

124. Justice Scalia also examines the legislative history of the Independent Prosecutor Act in this opinion, in part to demonstrate that it will be more difficult to fire Morrison than the majority suggests. Id. at 2627. This contradicts his own rule for determining the coustitutionality of statutes, set forth in Edwards v. Aguillard, 482 U.S. 578, 637 (1987) (dissenting), that legislative history is of no use. See supra text accompanying notes 21-23.

125. Note, Is Prosecution a Core Executive Function? Morrison v. Olson and the Framers' Intent, 99 YALE L.J. 1069, 1071-72, 1082-88 (1990). For an argument that Justice Scalia's formalist approach to separation of powers issues in this case contradicts both the theory and the practices of the late eighteenth ccntury, see Bloch, The Early Role of the Attorney General in Our Constitutional Scheme: In the Beginning There Was Pragmatism, 1989 DuKe L.J. 561, 643-46.

126. 109 S. Ct. 647, 675 (1989) (dissenting).

127. J. Locke, Second Treatise of Government 87 (R. Cox ed. 1982).

128. Id. at 682 (quoting from The Federalist No. 47, at 325-26 (J. Madison) (J. Cooke ed. 1961)). Justice Scalia does not hesitate to divine Madison's reaction to Justice Blackmun's interpretation: "He would be aghast ...." Id. at 683 . 
against the Coininonwealth of Pennsylvania in federal court. ${ }^{129}$ Although Justice Scalia agreed that the legislation authorized such a claim, he argued that the eleventh amendment ${ }^{130}$ renders such clains unconstitutional. Justice Scalia conceded:

If [the eleventh amendment] were intended as a comprehensive description of state sovereign iminumity in federal courts . . . then it would unquestionably be most reasonable to interpret it as providing immunity only when the sole basis of federal jurisdiction is the diversity of citizenship that it describes .... Unless some other constitutional principle beyond the immediate text of the Eleventh Amendment confers imınunity ... sovereign immunity would not exist so long as one of the other, nondiversity grounds of jurisdiction existed. 131

Thus, if the eleventh amendment were a statute (by its language, it could well be a part of the statute conferring diversity jurisdiction on the federal court), then the inquiry would be over according to Justice Scalia. But since we are looking at the Constitution, we must look for another "constitutional principle." 132 No other constitutional clause appears to fit the situation; the best candidate is article III, section 2, which allows for "judicial power" over "all cases, in Law and Equity, arising under . . . the Laws of the United States . . . or between a State and Citizens of another State." Despite this grant of authority arising fron the text, Justice Scalia finds that a different "constitutional principle" slould decide the case: sovereign immunity. ${ }^{133}$ Because the eleventlı amendment, ac-

129. 109 S. Ct. 2273, 2276 (1989) (Brennan, J., plurality).

130. "The Judicial power of the United States shall not be construed to extend to any suit in law or equity, commenced or prosecuted against one of the United States by Citizens of another State, or by Citizens or Subjects of any Foreign State." U.S. CoNST. amend. XI.

131. Union Gas, $109 \mathrm{~S}$. Ct. at 2296 (concurring in part and dissenting in part). At least one scholar has reached the opposite conclusion from the text itself. Lawrence Marshall, Fighting the Words of the Eleventh Amendment, 102 HARv. L. REv. 1342, 1347 (1989) (noting that the text refers to "any suit in law or equity").

132. In Union Gas, Justice Scalia interprets both a statute and the eleventh amendment. Thus, his opposing approaches appear especially clear. Compare "It is our task, as I see it, not to enter the minds of the Members of Congress-who need have nothing in mind in order for their votes to be both lawful and effective - but rather to find fair and reasonable meaning to the text of the United States Code ....", 109 S. Ct. at 2296 with "the Eleventh Amendment was important not merely for what it said but for what it reflected ... the understood background against which the Constitution was adopted ...." Id. at 2297.

133. "Sovereign immunity" is a constitutional principle to Justice Scalia, even though it never appears in the text. The concept does appear in Justice Iredell's dissent in Chisolm v. Georgia, 2 U.S. (2 Dall.) 419, 449-50 (1793), which Justice Scalia, following Hans v. Louisiana, 134 U.S. 1 (1890), believes provides the true meaning of the eleventh amendment. Although the eleventh amendment was passed in order to overrule the Chisholm decision, it is unclear why Justice Iredell's dissent has any special power. Compare Blanchard v. Bergeron, 109 S. Ct. 939, 947 (1989) (concurring in part) (asserting that the Supreme Court, when interpreting a statute, should accord no weight to a congressional committce report endorsing particular cases); see supra text accompanying notes $11-13,68$. 
cording to Justice Scalia, was meant not merely to limit diversity jurisdiction but also to incorporate the concept of state sovereign immunity into constitutional limits of federal court jurisdiction, ${ }^{134}$ federal courts have no jurisdiction over a Superfund indemnity claim against a state. Thus, Justice Scalia follows the originalist approach even in imterpreting an amendment to the Constitution (which, after all, he said is like a statute), notably an amendinent that sounds like a statute, and he concedes in his opinion that a textualist should reach the opposite result. The decision makes federal courts unavailable to citizens whose statutory rights have been violated by their state governments.

\section{B. Effect on Balance Between Legislative and Judicial Branches}

An originalist judge must begin with inquiry into the constitutionality of legislation from the attitude of the Frainers. An originalist refuses to defer to another conteinporary decisionmaker concerning the constitutionality of a particular law or action because what matters is not what the decisionmaker beheved, but rather what the Framers (or the authors of the Federalist Papers) thought. Thus, the fact that Congress believed an enactinent to be within its jurisdiction inerits no particular deference. Justice Scalia articulates this principle exphicitly in the Morrison v. Olson dissent:

It is rare in a case dealing, as this one does, with the constitutionality of a statute passed by the Congress of the United States, not to find anywhere in the Court's opinion the usual, alniost formulary caution that we owe great deference to Congress' view that what it has done is constitutional. ... That caution is not recited by the court in the present case because it does not apply.... [W] here the issue pertains to separation of powers, and the pohtical branches are (as here) in disagreeinent, neither can be presuined correct. ${ }^{135}$

This logic is clearly at odds with the reasoning Justice Scahia applies when an administrative agency appears to have overstepped its statutory powers-there "it is settled law that the rule of deference applies even to an agency's interpretation of its own statutory authority or jurisdiction."136 Thus, in Justice Scalia's umiverse, only unelected officials inay

Justice Scalia also cites a 1934 Supreme Court decision, Monaco v. Mississippi, 292 U.S. 313, 322-23 (1934), that relied on the version of sovereign immunity described in THE FEDERALIST No. 81. Union Gas, 109 S. Ct. at 2297.

134. Thus the eleventh amendment means that a federal court considering a claim against a state should presume that the state would have been immune from suit in its own courts in this claim, and dismiss the case on that basis. The distance between that interpretation and the text, see note 130 supra, is obvious.

135. 487 U.S. 654, 703-05 (1988) (dissenting).

136. Mississippi Power \& Light Co. v. Mississippi ex rel. Moore, 487 U.S. 354, 381 (1988) (concurring). 
decide the limits of their own authority without interference from the courts.

Originalism also makes a Supreme Court Justice's particular theory of the Constitution more important: If a Justice believes the law would not have been approved by the Framers, then a law has no effect, regardless of its historical or substantive significance. As a result, an originalist may have relatively hittle respect for the doctrine of stare decisis. ${ }^{137}$

\section{Effect on Balance Between Legislative and Executive Branches}

As several of the cases demonstrate, Justice Scalia recognizes that textualism with statutes reduces the power of individual Members of Congress: They can no longer express their intentions effectively in any way other than incorporating them in the legislation itself. Obviously, this requirement means that all interpreters of legislation would have fewer constramts than if they were expected to consider the original intent of the legislators. For example, a judge would not need to follow the cases Congress approved when deciding how to calculate attorney fees, since he could do anything the broad words of the statutes will allow. ${ }^{138}$

This discretion benefits not only judges and Justices, but the President and the executive agencies that make administrative decisions inplementing (or failing to implement) legislation. Justice Scalia clearly intends this result: Agents of the executive should have the authority to interpret legislation as they choose. ${ }^{139}$ Indeed, he occasionally has implored executive agencies to ignore congressional intent whenever the administration disagrees with it. ${ }^{140}$ If he were able to convince the remainder of the Court to follow lim, then both executive and judicial agents, when it comes to deciding how to enforce a statute, would have greater power than they now have.

137. Justice Scalia does not believe in the strongest versions of stare decisis, especially in the area of constitutional decisions. See, e.g., South Carolina v. Gatliers, 109 S. Ct. 2207, 2217 (1989) (dissenting) (advocating overturning two-year old precedent in eiglith amendment case, and allowing victim impact stateinents to be considered at capital sentencing hearings); Webster v. Reproductive Hcalth Servs., 109 S. Ct. 3040, 3066-67 (1989) (concurring in the judgment) (advocating overturning Roe v. Wade).

138. Blancliard v. Bergeron, 109 S. Ct. $939,946-47$ (concurring in part and concurring in the judgment); see supra text accoinpanying notes 11-13, 68 .

139. United States v. Stuart, 109 S. Ct. 1183, 1196 (1989) (concurring).

140. Scalia, supra note 54, at 513 (citing S. Doc. No. 8, 77tlı Cong., 1st Sess. 90-91 (1941)). Interestingly, Justice Scalia bases this principle on a conceded inputation of legislative intent. Id. at 517. 


\section{The Message to Administrative Decisionmakers}

Justice Scalia believes that the Supreme Court should be conscious of its position within the United States government; its decisions not only decide the cases before it but also communicate with other branches of government and with the people. ${ }^{141}$ But this perspective should apply equally to the legislative branch and suggests an appropriate role for legislative history.

One reason Members of Congress create committee reports is to communicate with the administrative agencies that exercise statutory responsibility for proninlgating rules and enforcing the laws. Whether or not information in a report is legally binding, it is the best evidence available to the administrator of the views lield by those who wrote the statute. This evidence can be a valuable starting point for the agency, even if they assunie sonre discretion over the nratter. ${ }^{142}$ Agency administrators are aware that suggestions in the legislative history were intended to guide them, and they shonld know they may be called to explain their actions if they fail to act in accordance with Congress's will. ${ }^{143}$

Justice Scalia offers a contradictory, equally clear message: An administrator may be called on to testify before Congress, but he has no reason to be concerned about what he hears. ${ }^{144}$ Because the words that appear in the committee reports or inl oral testimony are not part of a properly enacted statute presented to the President, they have no significance. According to Justice Scalia's view, testimony on the Hill, and of correspondence between Congress and the agency, are just rituals. ${ }^{145}$

141. Thus, he defends the Chevron rule of deference to administrative decisionmakers as a clear message to other decisionmakers. Scalia, supra note 54, at 516-18. On the other hand, he criticizes Justice O'Connor's abortion jurisprudence for sending unclear and wrong messages to the American people regarding the role of the Supreme Court in political decsionmaking. Webster v. Reproductive Health Servs., 109 S. Ct. 3040, 3065-66 (concurring in the judgment).

142. Justice Scalia uses such a passage of legislative history in Center for Auto Safety v. Peck, 751 F.2d 1336, 1350-51 (D.C. Cir. 1985) (majority).

143. See generally Shapiro \& Glicksinan, supra note 59.

144. Nor need the administrator pay very much attention to what he says, since absolute prosecutorial discretion should protect him from any perjury investigation by the Attorney General's office, and the independent counsel statute should be unconstitutional. After all, the underlying controversy in Morrison $v$. Olson was a grand jury investigation for perjury before a congressional committee. In re Sealed Case, 838 F.2d 476, 479 (D.C. Cir.), rev'd sub nom. Morrison v. Olson, 487 U.S. 654 (1988).

145. For critical examinations of the informal give-and-take between Congress and administrative agencies, see Hill, The Third House of Congress Versus the Fourth Branch of Govermment: The Impact of Congressional Committee Staff on Agency Regulatory Decisionmaking, 19 J. MARSHALI L. REV. 247 (1986) (stressing that neither administrators nor committee staff are elected); Shaman, The Use of Congressional Committee Reports in the Administrative Process, 6 IND. L. REv. 481 (1973) (committee reports should have no authority).

The arguments relating to the fact that Congressmen act through their aids are unconvincing. All government officials act through their staffs to varying degrees. As explained supra in note 10, 
Instead, agency administrators have only two sources for authority: The statutes and the President. ${ }^{146}$ They have, of course, broad interpretative authority over the statutes. At the same time, the President has broad authority over the administrators: The Constitution permits no administrative allocation of power unless the President retains the power to appoint and to fire the officer. ${ }^{147}$ And this configuration of power should please the Executive-a power-hungry President would give unqualified endorsement to such an allocation of authority. It is unsurprising that the Justice Department's Office of Legal Pohicy has endorsed the views Justice Scalia espouses. ${ }^{148}$

\section{CONCLUSION}

Justice Scahia presented a theory of the Constitution in a recent speech honoring President and Chief Justice Taft, that he attributed to Taft but also appears to endorse as the proper approach given the Constitution's place in historical context:

[T] he traditional English understanding of executive power, or, to be more precise, royal prerogatives, was fairly well known to the founding generation, simce they appear repeatedly in the text of the Constitution in formulations very similar to those found in Blackstone. It can further be argued that when those prerogatives were to be reallocated in whole or in part to other branches of government, or were to be linnited in soine other way, the Constitution generally did so expressly. One could reasonably infer, therefore, that what was not expressly reassigned would - at least absent some patent incompatibility with republican primciples-reenain with the executive. ${ }^{149}$

the fact that a President's aide or his astrologer recommended that the President veto a bill and wrote the veto message, or that a clerk wrote a Supreme Conrt opinion, does not reduce the authority of the written documents.

146. Logically, there is a third source of authority: the United States Constitution. An originalist agency head might well find that its agency could not perform a legislatively mandated function because its performance of that function would violate the Constitution. For a description of a controversy involving an agency's refusal to act on a law it believed unconstitutional, see P. SHANE \& H. BRuff, The LAW of Presidential Power $397-406$ (1987) (Department of Defense refused to comply with "stay" provision in Competition in Contractiug Act of 1984, because it believed the provision violated separation of powers; stay provision later found to be constitutional). See generally Note, The Authority of Administrative Agencies to Consider the Constitutionality of Statutes, 90 HARV. L. REV. 1682 (1977).

147. Morrison, 487 U.S. at 697.

148. OfFice of Legal Policy, supra note 31, at iii-v; see also Office of Legal Policy, ORIGINAL MEANING JURISPRUDENCE: A SOURCEBOOK (1987) (advocatiug that judges decide cases according to "original meaning" of the Constitution).

149. Scalia, supra note 76 , at 859-60.

An extended discussion of the difficulties a textualist should have with this interpretation is beyond the scope of this Note. It appears to be inconsistent with the following portions of the text: U.S. CoNST. art. I, § 8, cl. 18 (granting Legislature power to "make all laws which shall be necessary and proper for carrying into Execution the foregoing powers"); id. art. II, $\S \S 2-3$ (enumeratiug the 
Thus, the non-textual, historical context of the Constitution creates an Executive with powers based on those of the British king, a legislative branch with enumerated powers that can be exercised only by majority or two-thirds votes (in the case of a veto), ${ }^{150}$ and a judiciary with the power to decide only "cases and controversies," 151 a judiciary which must defer to the Executive's but not the Legislature's interpretations of their own power.

Clearly, Justice Scaha's treatinent of secondary sources for statutes and the Constitution mirrors the hierarchy he assumes for the executive and legislative branches. He uses outside sources regularly when they tend to decrease the power of the Congress and abjures outside sources when they increase the power of Congress.

It would be unfair to Justice Scalia to connect his belief im the supremacy of the executive over the legislature to the fact that since he has been on the bench, he has been facing executive actions by members of his own political party and legislative actions by the opposition

powers of the executive, without any mention of royal prerogatives), and id. amend. $\mathrm{X}$ ("The powers not delegated to the United States by the Constitution, nor prohibited by it to the States, are reserved to the States respectively, or to the people," not to the executive).

This interpretation also differs from the leading current historical interpretation of the meaning of "executive power" at the time of the Constitution. See, e.g., F. MCDonald, Novus Ordo SECLORUM 247-49 (1985) (with regard to Executive powers, "experience with colonial and state governors was largely irrelevant"; the drafters "expressly rejected the [royal] prerogative as a guide.")

Many non-textualists also would find this theory objectionable. A common argument for reinterpretation of the Constitution is that technological changes have increased opportunities for tyranny by the executive branch, especially the executive's police force. Consider Justice Brandeis' argument that warrantless wiretaps should be unconstitutional:

When the Fourth and Fifth Amendinents were adopted, "the form that evil had thereto-

fore taken" had been necessarily simple. Force and violence were then the only means

known to man by which a government could directly effect self-incrimination. . . . But

"tine works changes, brings into existence new conditions and purposes." Subtler and more far-reaching ineans of invading privacy have becone available to the government.

Discovery and invention have made it possible for the government, by means far more effective than stretching upon the rack, to obtain disclosure in court of what is whispered in the closet. ...

Moreover, "in the apphication of a Constitution, our contemplation eannot be ouly of what has been, but of what niay be." The progress of science in furnishing the government with means of espionage is not likely to stop with wire tapping. . . . Can it be that the Constitution affords no protection against such invasions of individual security?

Olmstead v. United States, 277 U.S. 438, $473-74$ (1928) (Brandeis, J., dissenting).

150. See supra text accompanying notes $2-34$.

151. See Honig v. Doe, 484 U.S. $340-41$ (1988) (dissenting) (arguing that a matter had become moot after oral argument at the Suprente Court). 
party. ${ }^{152}$ Indeed, Justice Scalia has held similar views at least since he was an Assistant Attorney General. ${ }^{153}$

Still, the use of legislative history makes a difference. It affects the outcome of Supreme Court decisions, but more importantly it affects the decisionmaking process of administrative agencies, whose discretionary judgments rarely will be reviewed by a court. Justice Scalia's approach, if adopted by the agencies, will free the courts and the agencies from constraints placed on them by Congress, yet it will maintain the constraints on Congress (and on state legislatures) created by the courts with respect to constitutional interpretations. Although saving us from the prospect of legislative tyranny, Justice Scalia's view makes it more diffcult for the legislature to save the people from executive tyranny (or, for that matter, judicial tyranny). Taken together, these rules of interpretation reduce the power of the most democratic branch of government, thereby making America less a democracy and more a bureaucratic state. When Justice Scalia reduces the ability of elective representatives to communicate with and coerce the executive branch, he is taking power away from the people. Those who support granting the more democratic branches of government a predominate role among the branches should consider Justice Scalia's warning in Morrison v. Olson:

That is what this suit is about. Power. ${ }^{154}$

Arthur Stock

152. It will be interesting to see whether Justice Scalia modifies his stance in favor of executive power when future executives no longer share his substantive political views. $C f$. Wolfman, Silver \& Silver, The Behavior of Justice Douglas in Federal Tax Cases, 122 U. PA. L. Rev 235 (1973) (tracing Justice Douglas' gradual shift from defender of the government to the Justice most likely to oppose it).

153. See 1976 Bicentennial Institute, supra note 64, at $684-98$ (1976).

154. 487 U.S. 654, 699 (1988) (dissenting). 